\title{
RISK UNIVERSITY: UNCERTAINTY OF THE LATE MODERNITY COMING TOO EARLY
}

\author{
MARCIN DEUTSCHMANN ${ }^{1} \&$ MICHAŁ WANKE ${ }^{2}$ \\ ${ }^{1}$ University of Opole, Faculty of Philology, Institute of Linguistics, Plac Kopernika 11, 45-040 Opole, \\ Poland. ORCID: 0000-0001-6281-6134,Email: marcin.deutschmann@uni.opole.pl \\ ${ }^{2}$ University of Opole, Faculty of Social Sciences, Department of Sociological Sciences and So- \\ cial Work, Katowicka 89, 45-061 Opole, Poland. ORCID: 0000-0003-0413-9838, Email: \\ michal.wanke@uni.opole.pl
}

ABSTRACT: The study examines how a regional university, having recently overseen a dramatic internationalization, deals with the consequences of COVID-19, and how the students - many of whom are international and coming from the global peripheries experience the pandemic. The study is informed by the critical theory of late modernity and capitalism - especially the theory of uncertainty and risk (Beck, 1992; Beck, Giddens, \& Lash 1994). It explores the power relations of the communicative dynamic between the administrators managing the crisis and the students perceiving and living it. It is an early-stage research report, published days after a pilot study was run. A survey among international students (including local, tuition-fee paying, and exchange students) was distributed to obtain initial responses. The analysis is complemented by insights based on close observation of the unfolding situation and analysis of the documents issued by the university. The findings explain the uncertainty experienced by international students, characteristic of many CE universities. The study covers the topics of attitudes towards epidemics, information imbalance, perception of security, and evaluation of the responses. The paper concludes with an urgent call to recently internationalized universities for a recognition of the complexity of students' fears. KEYWORDS: COVID-19, pandemic, risk, uncertainty, late modernity, critical theory, peripheries, crisis communication 


\section{TRYING TO GRASP A CHANGE COMING TOO EARLY}

We are witnesses of a great social experiment and at the same time a big social change, at least a temporal one. The pandemic caused by the novel coronavirus proves to have transformative potential, as did the other great epidemics studied by sociologists, like HIV/AIDS (Lupton 1994). Moreover, it is also obviously fundamental for sociology to document the change in general. The change we are attempting to capture is deeply (and irrationally ${ }^{1}$ ) unexpected, rapid, even given the accelerating nature of the social reality (Hsu, Elliott, 2014), thorough and comprehensive. It encapsulates all dimensions of social lives, both of groups and individuals: economic, interactive, mediated, and ritual - power relations and structures as well as identities and selves we live by.

This paper has two specific aims, apart from a general sociological response to the shifting social reality. First, it is to examine how an international university in Eastern Europe deals with the consequences of the COVID-19, and second, how the students experience the epidemics. It must be stressed that Poland has only recently seen a sharp increase in internationalization rates and is a novice, institutionally and socially speaking. Moreover, compared to the Western European parts of the EU academic market, Poland is significantly cheaper and attracts students of the global periphery rather than centers, which results in the students having fewer resources (in terms of all kinds of capital) and being much more vulnerable than those who study in established universities, which results in different effects of the pandemic when compared to more affluent international students (Ye, 2020). Both the institutions and the students have hence only recently gone through a transition into the realm of international academia, and they are unprepared for yet another change, with the internationalization of higher education being a completely new context to both parties.

We are convinced our rapid response is very much needed to address the radical uncertainty (Pieri, 2020) that has an impact on the experience of the 'new normal' (Waltner-Toews et al., 2020) full of hazards. Sociologists have been theorizing the risk in the context of late modernity for decades now with Ulrich Beck (1992) being the main reference author.

We are seeking to present the university as an example of a peripheral, yet globally interconnected, international university that is additionally embedded in national regulations and directives from the Ministry of Science and Higher Education.

A survey was distributed among the students of international programmes as an immediate response to the unfolding situation in order to obtain their reactions and evaluations in the form of closed- and open-ended questions. This paper attempts to provide an overview of the issues which affect international students of the global peripheries, an already at-risk population.

\footnotetext{
${ }^{1}$ As Zeynep Tufekci (2020) argues, not only individuals, but also media organizations and leaders struggled to foresee the obvious consequences of the unfolding epidemics due to the complexity of the phenomenon.
} 


\section{LAGGING REFLEXIVITY OF THE RISK UNIVERSITY}

Academia, including public universities have been a subject of critique inherently present in its operation (eg. Bourdieu 1988). The recent transformations (together with late modern societies) towards neo-liberal are frequent subjects of these critical analyses (Holmwood, Chaime 2019). Global higher education intensifies commodification of knowledge, fetishizies social mobility and exploits the tuition fee paying students' resources. The recent protests in well-established academias of the United Kingdom or the Netherlands unveil some critical responses of the community towards its constant technocratic and hyper competitive shifts. Regardless of these efforts the capitalist logic underlines the university operation, and the strikes serve as the indicators rather than solutions of the problem at the moment.

The optimization of functioning of the universities-as-companies involves risk assessment and governance (eg. Huber 2011). It means to improve the effectiveness, including economic performance of the university, rather than engage critically with what Ulrich Beck (1992) theorized as the organizing principle of the late modern societies. This paper is informed by the latter perspective. We follow the analysis of the notion of the 'risk university' (Robertson, Muellerleile 2016), recognizing the basic contradiction of the risk society, namely the modernization processes adding to the complexity of the globalized and interconnected society. This produces or induces the risks that the modern societies in turn strive to reduce and counteract. The 'risk university' is the one - paradoxically - that addresses the 'hazards' of capitalist logic instead of reflexively inquiring into the processes that are responsible for the situation in the first place.

Some Polish universities follow other European higher education institutions' efforts to close the gap created by decreasing local student populations. They are opening to the global educational markets. The efforts are made ad hoc, have often been coordinated recently if at all, and are mostly based on the geographical proximity and geopolitical situation of the students' countries of origin (Sin, Antonowicz, Wiers-Jenssen 2019), but they can be clearly theorised as a risk management strategy by those universities. With the abundance of international students, they are reducing the uncertainty revolving around their very purpose of existence.

In turn, the students are attracted by the prospect of a European Union diploma and relatively low tuition fees, trying to manage the risks of the late-capitalist order and buying into the logic of meritocratic promise of social mobility.

As Urlich Beck (2010) noticed, the risks are unevenly distributed. In case of some universities, the tuition fees are significant additions to the institutions' budgets, but these are the students who 'invest' in their education and are in this respect totally dependent on the university. Their dependence starts with the dormitories for accommodation, through the international offices facilitating the legal stay, campuses being the centers of the student's whereabouts and frequently the only reference points on a foreign soil, and finally the most important: the study programmes and the diplomas awarded. There is a significant power imbalance between the university administration and international students. 
Until now, standard discussions about risk and health issues have concentrated around a few main topics, such as immunisation, eating and drinking, smoking and public health (Denney 2005). The pandemic and its consequences are new risks on this list. However, different kinds of epidemics, such as cholera, plague, the so-called Spanish Flu or Ebola have shown up many times in history and were rather associated as one of the risks of the premodern period in the same way as disease, war and failing harvests (Denney, 2005). However, for the very first time, the pandemic in times of modernity caused such harm to the global economy, politics and social life.

We argue that the university and the students apply different strategies to tackle the risk of the effects of the Covid-19 pandemic. The former is using the modernist instrumental rationality, mostly through the administrative regulations of the rector and the chancellor, informed by the legal publications of the sanitary or higher education institutions - or, in the peripheral model - more established universities. The latter use individualistic strategies to maintain both psychological and physical security, also using the experts' knowledge but in a less directly hierarchical relationship.

The research has been undertaken at a middle-sized university in Poland (Central-Eastern Europe). It is one of eighteen comprehensive public universities in Poland. Located in the South-West part of the country, between two bigger academic cities, the less established university center faces severe competition from the more advantaged neighbors. The university and the city are quite attractive for international students because costs of life and tuition fees are among the lowest in the country, and the town is very well connected to other, bigger cities and to many European capitals.

The university itself holds more than 100 study programmes and specialities. The population of students is almost 8000 and decreases every year (currently 7802 according to data from March 2020). The university experienced a dramatic internationalization in the last few years. Thanks to funds within various programmes (e.g. Erasmus+) the university was able to establish and develop many connections all around the world and start a few international studies programmes in English. Not so long ago, there existed three offices dedicated to foreign students at the university:

(i) The Center for the Eastern Partnership (CEP) - dedicated to students who come from the countries of the Eastern Partnership (a majority of whom being Ukrainian) and study mostly in Polish. Merged with the Student Affairs office after the reform in the Polish law and change of the structure of the university.

(ii) The Erasmus+ Office (EO) - dedicated to the incoming and outgoing mobility programmes. The office oversees the students in exchange programs.

(iii) The Office for International Study Programmes - created in January 2017 was closed in September 2020 due to the aforementioned structural changes of the university - its competences shifted to the Student Affairs office and EO). Its intended function was to take care of regular students.

As a consequence of these actions and processes, right now (March 2020) 7,6\% of the university's regular students (studying towards bachelor's, master's or doctoral 
degrees) are foreigners. Additionally, there are 88 Erasmus students, so altogether, $8,7 \%$ of the university's students are not citizens of Poland. Because the internationalization of the university at this scale is quite a new phenomenon, there are numerous problems, specific to such a rapid internationalization, faced by students, teachers and administrators who take part in this process. Because of the coronavirus, these problems became much more urgent than they were before, and additionally, some new problems emerged in the context of internationalization.

We would like to highlight that there are important reasons to look into internationalization of higher education in the context of spreading pandemic, as with the foreign students both them and the institution are exposed to potential harms. One hand, international students are much more mobile than local students and hence more prone to transmit the contagious disease, what poses a threat to themselves and to the university that would otherwise be more isolated. On the other hand, they are put under enormous pressure, incomparable to the local students. They are far from their homes, want to (or sometimes are forced to) go back to their countries, and at the same moment are excluded from most information in their current place of stay, just because of unavailability of information in their own language or even in English. Now, the students stay in isolation and face a discrepancy of information from different sources. Lacking social capital in the host country, they cannot return home like the majority of the native students.

There are several kinds of such students at the university:

(i) Incoming exchange students - especially the Erasmus+ program students. They are defined by the temporariness and the timing of their situation. They are supposed to stay at the university until the end of the semester. It is not clear what happens next in terms of academic teaching, and many of them arrived just at the beginning of the outbreak.

(ii) Outgoing Erasmus students - the local, full-time students in various parts of the World, especially Europe. They are dependent not only on their own university regulations and support but also on the support of the university where they study currently. Moreover, the Polish government and other governments take actions that are often unilateral. The borders would be closed, so only Polish students can come back home, and to the university. But many of these students are tuition fee-paying foreigners. They cannot come back to the university; they can only go back home.

(iii) Foreign students who pay tuition fee and study towards diploma. Admittedly their life and plans are more stable; they come to study for two or three years, usually already have developed networks of friends (fellow internationals), and plan to stay here for longer. Some of them went back to their home countries for winter break, and are not able to come back (e.g. from Iran). They are in relatively good condition - staying at home. They are able to use the resources of the family and simultaneously they can participate in classes online.

The Polish government, similarly to other governments in Europe and outside of 
the Old Continent, have made some radical and strict decisions to limit the spread of the coronavirus pandemic. The new laws, regarding many different areas of social life, have been implemented in Poland in the form of the state law passed by the national parliament, or in the form of specific ministers' regulations.

On the 2nd of March 2020, the Polish parliament adopted the legal act on specific solutions related to the prevention, counteraction and eradication of COVID-19, and other infectious diseases and crisis situations caused by them (position 374). The act allows workers, for example, to work remotely (if possible). It gives additional social care options for parents with children, and maximum prices of specific goods (such as respirators and other personal hygiene products) were implemented by the Minister of Health, providing restrictions in case of epidemiological danger.

On the 11th of March 2020, there was a crucial day for the implementation of restrictions on the territory of Poland. On this day the Minister of Health added the virus SARS-CoV-2, and illnesses caused by it, to the list of illnesses that cause hospitalization (Regulation of the Minister of Health of March 11, 2020, amending the regulation on the list of diseases that cause hospitalization, position 409). Moreover, the Minister of National Education published the regulation that from 16th March 2020 till 25th March 2020 all schools and kindergartens are closed, and classes are suspended (REGULATION OF THE MINISTER OF NATIONAL EDUCATION of 11 March 2020 on the temporary limitation of the functioning of educational system units in connection with the prevention, prevention and combating of COVID-19, position 410).

On the 13th of March 2020, the government published another series of legal acts related to the virus SARS-CoV-2. The Minister of Health announced a state of epidemiological danger (Regulation of the Minister of Health of March 13, 2020, regarding the announcement of an epidemic emergency in the territory of the Republic of Poland, position 433).

Changes of the functioning of the Higher Education in Poland have been introduced by a series of regulations by the Minister of Science and Higher Education. In subsequent legal acts, the Minister decided to suspend all classes in studies, postgraduate studies, and other forms of teaching until March 25th (Regulation of the Minister of Science and Higher Education of 11th March 2020, position 405) with a later extension of this period to April 10th (Regulation of the Minister of Science and Higher Education of 23rd March 2020, position 511). The universities were encouraged to teach all courses online during the suspension time without the usual limitation of ECTS points being impossible to get remotely (Regulation of the Minister of Science and Higher Education of 11th March 2020, position 405). It extended the validity of students IDs (Regulation of the Minister of Science and Higher Education of 12th March 2020, position 420) and doctoral IDs (Regulation of the Minister of Science and Higher Education of 12th March 2020, position 418), released employees from the obligation to work in their workplace, with an exception for cases in which the job is necessary to ensure the continuity of the university's operation (Regulation of the Minister of Science and Higher Education of 16th March 2020, position 455), gave the possibility to continue online teaching and to validate learning effects online (Regulation of the Minister of Science and Higher Education of 23rd March 2020, position 511), and made 
it possible to make college decisions online (Regulation of the Minister of Science and Higher Education of 25th March 2020, position 528).

It is important to note that these regulations did not take into account the complicated situation of foreign students. Albeit, they gave a lot of new possibilities and freedom to the university authorities in terms of online decision making and establishing ways of e-learning at particular universities. Unfortunately, the regulators, as well as the university authorities, did not consider the problem of the digital divide, the lack of Internet connections and possible problematic access to devices. Moreover, many of these regulations remain unknown among students, especially foreign students, who often do not speak Polish and are unable to check these regulations on their own. This is why there is a crucial role and responsibility of university authorities, officers, and workers, in terms of effective communication policy and crisis management.

As a consequence of the government's regulations, the universities had to respond by introducing changes to their internal acts. At the university in question, the Rectors and the Chancellor responded with a series of internal regulations, which we will skip as they concern only university workers and will instead focus on those regarding the students directly. In cooperation with the Sanitary Office, the university's authorities implemented a rule that all students coming from abroad must spend fourteen days in quarantine.

The very first regulation of the rector of the university, from February 28th, was a ban on all travels of staff, students and doctoral students to and from countries defined as countries of higher risk. In the beginning, the regulation included the list of banned countries, but later the record was changed and referred to the list on the website of the State Sanitary Inspection (change on March 6th). On March 10th, a day before the government's regulation, due to the decision of the alliance of a few universities in the region, the rector suspended classes from March 11th until further notice, and cancelled all international travels, all university's events, and banned the lodging of new people in the dormitories. The decision was surprising to the academic community because there was no information about further steps. On March 11th the Rector of Teaching and Student Affairs, in a letter to the Deans and study coordinators, recommended e-learning. On March 13th another regulation was published with the details about remote work for the university's administration. As of March 16th, due to the rector's regulation, all consultations with students should be done remotely via phone or internet, and university offices should work mostly remotely, with limited office hours. There was not one system, recommendation or regulation about teaching tools for the whole university so teachers could creatively decide how they would accomplish e-learning. Some deans recommended using various open-source software, so as not to overload the university's servers. The information about the online form of class and teacher contact has been published on each faculty's website.

On March 18th, one of the more important regulations appeared. The dormitory was closed for people who do not live there, and a curfew was set for its inhabitants from $10 \mathrm{pm}$ till $6 \mathrm{am}$. Only people who could prove that they work after these hours could enter the dormitory later than $10 \mathrm{pm}$.

Additionally, due to many student questions on the main university's website, FAQ 
was published and are continually updated. However, at the moment of submitting this text, the latest Polish version has been updated on March 25th and contains answers for 23 questions, and the latest English version from March 17th contains 23 questions. However, there is a significant discrepancy between one of the answers and the current state of affairs. The information on the website states that there is no plan to close dormitories, but according to the local media news from March 27th, one of the dormitories has to be emptied by the end of March and will be at the regional government's disposal. It is the decision of higher authorities, but there is still no official information on the university website, or internal documents, which causes many questions from students and mistrust of the university's statements.

In order to make sense of the crisis situation, steps have been taken by local sociologists to facilitate the monitoring of the problem. The calls for integrated communication policy, coordinating actions with the sanitary services amid the returns of students from China and Southeast Asia, or Ukraine (with economic/migratory ties to Northern Italy), were dismissed by administrators of the university as panic. Therefore, a survey was constructed in order to monitor the situation of the international students in the wake of the pandemic. The participants from Azerbaijan, Cameroon, Croatia, Ethiopia, Iran, Nigeria, Poland, and Turkey responded to the initial call distributed among the class of quantitative analysis in the summer semester of the academic year 2019/2020. Most of these students are tuition fee paying students, but there are also Erasmus+ program participants and regular Polish and EU students (not obliged to pay any fee). At the moment, most of these participants stay in the town, in one of the university dormitories, but some of them reside in family homes nearby (Polish students) or in their home countries (foreigners who went for the semester break and could not come back because of the restrictions related to the pandemic). One of the students is currently on Erasmus mobility at a different university in Greece. It is a pilot study before much wider research, which is planned to be carried out within this course with the students in the coming weeks, on a much more extensive sample, including other international universities. Therefore, the aim of this early stage analysis is purely exploratory.

\section{DEFERRED PERCEPTION AND THE CONSUMPTION OF RISK}

All the research participants heard about the virus when the epidemics broke out in China, but they downplayed the potential effects using multiple strategies characteristic of late modernity. First of all, some approached it as a mediated (and hence, remote) danger, that has been normalized as a part of the everyday experience and is rendered as part of the complexity of modernity.

I didn't care much. Every year there is a new virus that comes and "kills" thousands of people (or animals), and some governments over-react the situation to hide their corruption with new "problem", the biggest part of the population is not affected by anything or just "goes through" it and overcome virus/infection by medicament or natural immunity, so I can say that I got used to it, and it did not mean to me much. It's like a war for most of the people, as long as it is far 
from sight, nobody cares (m_Cro_30) ${ }^{2}$.

There is significant mistrust towards the government's actions expressed in this quotation and the expectation to dramatize the risk. Furthermore, there are references to some scientific rationale (and language), applying the internalized expert's knowledge to normalize the phenomenon. Anthony Giddens (2013) famously called it 'double hermeneutics,' characteristic of reflexive modernity and individual strategies to build ontological security (Giddens, 1991).

Secondly, some tried to distance the problem from themselves in various ways and kept certain remoteness to the problem. They did not consider the problem as just a mediated issue - they would admit it was a real problem, but with spatially limited impact, not affecting their territory:

(1) I thought it would stay in China, and they will find a solution (f_Tr_25).

(2) I didn't take it seriously because I had hoped that China would put it under control and never imagined it would expand to the world like this (m_Eth_27).

(3) I did not expect that it will spread around the world and will affect the people in this scale (m_Tr_25).

(4) I didn’t think Europe would be harmed (f_Tr_21b).

(5) When I heard about coronavirus for the very first time, I thought it concerns only China. I didn't even expect that it would affect Poland (f_Tr_21a).

(6) I never thought it would come this close to me (m_Cam_30).

In the six statements above, it is visible how the respondents use the same strategy to distance the problem from themselves in a different way. In the statement 1 . and 2 . they limited the virus to the status of the regional problem of just one country, which can probably resolve the issue, so it wouldn't spread further. In the following comments from different participants, they did not reduce the virus to just one country, but still did not consider it as a global issue. In the subsequent statement, the virus is not considered a problem which could reach Europe (4) or Poland (5), and even if it happened, there would be a medicine already. In the last statement the personal situation is considered. These five stages and distances (a local problem far away, global, European, national, personal) might be considered in further research as kinds of safety zones of problematic appropriation. Where is the border between a safe distance to the problem, and a distance at which the problem starts to bother a person and becomes a perceived danger?

Third of all, the students believed that a medical response to the new virus would be

\footnotetext{
${ }^{2}$ All quotations of students statements are coded according to the same key: the first part of the code indicates gender ( $\mathrm{f}$ - female, $\mathrm{m}$ - male), the second part of the code indicates the country of origin (Az Azerbaijan, Cam - Cameroon, Cro - Croatia, Eth - Ethiopia, Nig - Nigeria, Pol - Poland, Tr - Turkey_, the last part of the code indicates the age of the student. In case when the combination is similar for the certain student, we added letters a, b, c... in the end of the code.
} 
obvious and would come quickly, putting a significant amount of trust in the experts.

(1) I think a vaccine is coming soon! (m_Az_26)

(2) I thought medicine would be found for the coronavirus (f_Tr_21b)

This seems to be typical for the contemporary interpretations of death, diseases or catastrophes. According to these discourses, there are no unsolvable problems, because the expert society and its modernized technology hold all the solutions to possible problems. Everything is just a technical issue, including death. The virus is not just a killer anymore. People do not die just because there is a new deadly disease. People die because there is no medicine yet, but it is just a matter of time. Science can solve all problems, including death. It is worth noticing the exclamation mark in the first sentence. It has a purpose to strengthen the statement and show the strength of this trust in science and contemporary medicine.

The majority of participants are afraid of the pandemic (17), are annoyed because of the inconvenience (20), and are bored because they have to stay home (18). They individualize the risks and refer to themselves and their personal freedoms when assessing it with a somewhat consumerist style: complaining about the interrupted service' of everyday consumption. A student commenting on what has changed elaborates that her:

rate of shopping which is my hobby has reduced due to restrictions of often movements. Though sad but to an extent I am happy because this helped me to devote myself to savings. (f_Cam_26)

At the same time, 21 of the participants are curious about the current events. 14 participants think that from now on, everything will be different, and 9 people believe that the virus will be defeated soon, and 1 person thinks it will stay with us forever. When students consider the situation in the city and in Poland, they say that everyone is in panic. They also notice that people are supposed to stay home, but they can see a lot of people by windows, which seems contradictory.

Regarding the immediate risk, 15 out of 23 participants were afraid that they could get the virus, and only three of them are not afraid. One of students declared:

I can see the end, due to the numerous deaths (m_Cam_38).

At the same moment, the students are afraid not only about their personal health, but also about the local healthcare system in case of getting the disease. Another student says:

I'm a foreigner in Poland, and I'm so afraid that if I get the virus what will I do? We are facing racism here so if I go to the hospital I'm not so sure that they will take care of me (f_Tr_21c).

Besides their own health, they also think about their closest family and friends. 18 of the research participants are afraid that one of their close ones could get the virus, and only two of them are not afraid about it. So, more students are concerned about their close ones' health than their own. They declare: 
I am scared for my family life (f_Pol_23).

Locating the problem in the individual is in line with the subjective strategies underlined by the late modernity theorists. As one of the respondents put it:

Coronavirus has proved that everything around me is so temporary. things our lives revolved around... school, work, gym, malls, movies, society have all gone for a toss as we are learning to live without them. It has taught me that in the end, it's my own home and family that keeps me safe, and God too (m_Nig_28).

More than half of participants are stressed because their financial situation is getting worse now, and this is one of crucial points of students' uncertainty. They underline that they can't find a job because of the pandemic, and even when somebody has a job, she has to stay home because the workplace is closed. Moreover, they are afraid that even if the virus goes away, they will be stigmatized by employers because foreigners will stay suspicious.

We asked students also to evaluate the government's and university's policy towards coronavirus. These questions didn't mean to measure the real opinion about the governmental or university's actions, rather the feeling and the sense of security. Most students think that the government's actions are effective. Some student even declare:

Poland is the best at controlling this situation compared to the other European countries (f_Tr_21c).

18 students agree that universities' actions are reasonable. However, even if their general opinion and feeling about the university's actions is positive, they underline that their education stopped. They also noticed that the university is a place of higher risk, because there are a lot of youths who are exposed to the World.

The university started e-learning mode on March 16th, and 6 of the students evaluated it as a very good idea, while 11 declared it was okay, and two of them thought it was a bad idea. However, independently from these declarations students don't believe that e-learning is equal to classic lectures and classes. The fact about the university being closed is itself scary to the students.

My university is locked down and the opening day is not certain. This is the scary thing about my academic year (f_Tr_25).

All of this in general leads to international students' uncertainty: 19 participants of our research feel uncertain about their near future because of the pandemic.

I have no idea what will happen next (m_Eth_27).

They declare they try to live their lives normally, but that it's impossible:

The situation changed everything in my daily life. University is closed, my work is closed. I am at home all the time. I go out only for shopping. I am trying to have a normal life but it is impossible. I am doing something all the time (reading, cooking, cleaning) but it is not a normal situation. All the time I am scared that someone from my family, friends can be infected. All the time I have a bad moon, 
I cannot sleep. I am stressed all the time. I am afraid to turn on tv or the internet because there is still information about the next infected or dead (f_Pol_22).

The lack of information about system solutions leads students to uncertainty, and to making important decisions very rapidly, without a second thought, because there is no time for that.

Fear industry with the leading role of mass media creates the feeling of uncertainty and causes overestimation or underestimation of risk.

All the time I have a bad moon, I cannot sleep. I am stressed all the time. I am afraid to turn on the tv or the internet because there is still information about the next infected or dead. (f_Pol_22)

People look for safety and try to find it in their home, with family, even when objectively it would be better to stay where they are right now. It's not about the rational calculation, rather about the feeling of being safe. The good example are Spanish students who wave between staying in Poland and going home, and finally choose to go, even when the travel itself is risky, and in their point of destination, there are many more people who are infected and who actually die because of the virus.

\section{THE NEED FOR RAPID RESPONSES TO ACCELERATING PANDEMIC}

The survey done has a few significant limitations and constitutes a very early-stage piece of research of various phenomena connected to the pandemic of COVID-19. First of all, the sample size is too small to make any significant generalizations, even for one university (23 cases). However, the research purpose was to recognize the situation and possibilities for further investigations, and it was accomplished. Another step will be developed, in the form of a more detailed and deeper conceptualized questionnaire distributed among a statistically significant random sample of the university's international students.

Second of all, it is just a pilot study done at only one university, though the problems described seem to be much wider and typical for similar-sized universities in world's peripheries. To prove this we would like to perform similar research in a few different universities in the world ${ }^{3}$.

Third, the limitation is the survey questionnaire itself. In many cases, we decided to resign from the answers suggestions to gather qualitative data, which will be further used for the conceptualization of concepts and problems. In many cases, further conceptualization is badly needed. For example, when asking about the government or university's policy towards the crisis, the general feeling may be positive, but asking more specific questions, addressing more specific problems, may give us different results. The set of items has to be developed and specified.

There are certain implications to be drawn though. For university administrations - need to recognize uncertainty of the students too. For sociologists - the conceptualization of reflexive modernity in globalized education generates a new level of problems to address, especially amid the epidemics. Apart from the initial questions

\footnotetext{
${ }^{3}$ If you are interested in cooperation, please contact us.
} 
we posed, some further research questions we intend to ask touch upon the rapid distance learning revolution: what are the 'risks' of remote teaching and learning, who has skills and access and who has not? What amounts of immaterial, digital labor are to be performed and underpaid by the university staff (Woodcock, 2018)? What are the consequences of platformization of the university for privacy, surveillance, algorithmic governance etc. (Carrigan, 2020)?

The pandemics unveiled the contradictory dynamics of the risk university that is visible on the margins of global higher education. The more so, that both the change and the response comes late. Further research on this problem is needed to apply effective mechanisms to attempt to bypass the disadvantaged combination of the peripheral university and the students coming from the global South.

FUNDING: This research received no external funding.

CONFLICT OF INTEREST: The authors declare no conflict of interest.

ACKNOWLEDGEMENTS: The authors would like to thank Julia Dickenson, a Fulbright programme English Teaching Assistant at the University of Opole for her kind corrections made on her flight back home amid the Covid-19 pandemic.

\section{References}

Beck, Ulrich. 1992. Risk Society: Towards a New Modernity. London and New York: Sage. Beck, Ulrich. 2010. „Remapping social inequalities in an age of climate change: for a cosmopolitan renewal of sociology." Global Networks 10.2: 165-181. https://doi. org/10.1111/j.1471-0374.2010.00281.x

Beck, Ulrich, Anthony Giddens, \& Scott Lash. 1994. Reflexive modernization: Politics, tradition and aesthetics in the modern social order. Stanford: Stanford University Press.

Bourdieu, Pierre (1988). Homo Academicus. Cambridge, UK: Polity.

Carrigan, Mark. 2020. “The Platform University and COVID-19.” Discover Society. Retrieved 09.04.2020 (https://discoversociety.org/2020/04/07/the-platform-university-and-covid-19/).

Denney, David. 2005. Risk and Society. London: SAGE Publications Ltd.

Giddens, Anthony. 1991. Modernity and self-identity: Self and society in the late modern age. Stanford: Stanford University Press.

------. 2013. New rules of sociological method: A positive critique of interpretative sociologies. London: John Wiley \& Sons.

Holmwood, John and Chaime Marcuello Servos. 2019. „Challenges to Public Universities: Digitalisation, Commodification and Precarity.” Social Epistemology 33(4): 309-320. https://doi.org/10.1080/02691728.2019.1638986

Hsu, Eric L. \& Anthony Elliott. 2015. “Social acceleration theory and the self.” Journal for the Theory of Social Behaviour 45(4): 397-418. https://doi.org/10.1111/ 
jtsb. 1207

Huber, Michael. 2011. The risk university: Risk identification at higher education institutions in England. London: London School of Economics and Political Science. Retrieved April 9, 2020 (http://eprints.lse.ac.uk/38891/1/The_risk_university_Risk_ identification_at higher_education institutions in_England.pdf).

Lupton, Deborah. 1994. Moral threats and dangerous desires: AIDS in the news media. London: Routledge.

Pieri, Elisa. 2020. "Radical uncertainty, sociology and the social impacts of pandemic preparedness on citizens." Discover Society. Retrieved March 22, 2020 (https:// discoversociety.org/2020/03/21/radical-uncertainty-sociology-and-the-social-impacts-of-pandemic-preparedness-on-citizens/).

Robertson, Susan L. and Christopher Muellerleile. 2016. "Universities, the Risk Industry and Capitalism: A Political Economy Critique.” Pp. 122-139 in A European Politics of Education? Perspectives from Sociology, Policy Studies and Politics, edited by Romuald Normand and Jean Louis Derouet. London and New York: Routledge.

Rozporządzenie Ministra Edukacji Narodowej z dnia 11 marca 2020 r. w sprawie czasowego ograniczenia funkcjonowania jednostek systemu oświaty $\mathrm{w}$ związku $\mathrm{z}$ zapobieganiem, przeciwdziałaniem i zwalczaniem COVID-19 (Regulation of the Minister of National Education of 11 March 2020 on the temporary limitation of the functioning of educational system units in connection with the prevention, prevention and combating of COVID-19)

Rozporządzenie Ministra Nauki i Szkolnictwa Wyższego z dnia 11 marca 2020 r. w sprawie czasowego ograniczenia funkcjonowania niektórych podmiotów systemu szkolnictwa wyższego i nauki w związku z zapobieganiem, przeciwdziałaniem i zwalczaniem COVID-19 (Regulation of the Minister of Science and Higher Education of 11 March 2020 on the temporary limitation of the functioning of some entities in the higher education and science system in relation to the prevention, prevention and combating of COVID-19)

Rozporządzenie Ministra Nauki i Szkolnictwa Wyższego z dnia 12 marca 2020 r. zmieniające rozporządzenie w sprawie dyplomów doktorskich, dyplomów habilitacyjnych i legitymacji doktoranta (Regulation of the Minister of Science and Higher Education of 12 March 2020 amending the regulation on doctoral diplomas, habilitation diplomas and doctoral student ID)

Rozporządzenie Ministra Nauki i Szkolnictwa Wyższego z dnia 12 marca 2020 r. zmieniające rozporządzenie w sprawie studiów (Regulation of the Minister of Science and Higher Education of March 12, 2020 amending the regulation on studies)

Rozporządzenie Ministra Nauki i Szkolnictwa Wyższego z dnia 16 marca 2020 r. zmieniające rozporządzenie w sprawie czasowego ograniczenia funkcjonowania niektórych podmiotów systemu szkolnictwa wyższego i nauki w związku z zapobieganiem, przeciwdziałaniem i zwalczaniem COVID-19 (Regulation of the Minister of Science and Higher Education of 16 March 2020 amending the regulation on the temporary limitation of the functioning of certain entities in the higher education and science system in relation to the prevention, prevention and combating of COVID-19) 
Rozporządzenie Ministra Nauki i Szkolnictwa Wyższego z dnia 23 marca 2020 r. w sprawie czasowego ograniczenia funkcjonowania niektórych podmiotów systemu szkolnictwa wyższego i nauki w związku z zapobieganiem, przeciwdziałaniem i zwalczaniem COVID-19 (Regulation of the Minister of Science and Higher Education of 23 March 2020 on the temporary limitation of the functioning of some entities in the higher education and science system in relation to the prevention, prevention and combating of COVID-19)

Rozporządzenie Ministra Nauki i Szkolnictwa Wyższego z dnia 25 marca 2020 r. zmieniające rozporządzenie w sprawie czasowego ograniczenia funkcjonowania niektórych podmiotów systemu szkolnictwa wyższego i nauki w związku z zapobieganiem, przeciwdziałaniem i zwalczaniem COVID-19 (Regulation of the Minister of Science and Higher Education of 25 March 2020 amending the regulation on the temporary limitation of the functioning of certain entities in the higher education and science system in relation to the prevention, prevention and combating of COVID-19)

Rozporządzenie Ministra Zdrowia z dnia 11 marca 2020 r. zmieniające rozporządzenie w sprawie wykazu chorób powodujących powstanie obowiązku hospitalizacji (Regulation of the Minister of Health of March 11, 2020 amending the regulation on the list of diseases that cause hospitalization)

Rozporządzenie Ministra Zdrowia z dnia 13 marca 2020 r. w sprawie ogłoszenia na obszarze Rzeczypospolitej Polskiej stanu zagrożenia epidemicznego (Regulation of the Minister of Health of March 13, 2020 regarding the announcement of an epidemic emergency in the territory of the Republic of Poland, position 433)

Sin, Cristina, Dominik Antonowicz, \& Jannecke Wiers-Jenssen Attracting. 2019. “International Students to Semi-peripheral Countries: A Comparative Study of Norway, Poland and Portugal." Higher Education Policy 1-24. https://doi.org/10.1057/ s41307-019-00135-3

Tufekci, Zeynep. 2020. „It Wasn't Just Trump Who Got It Wrong. America's coronavirus response failed because we didn't understand the complexity of the problem." The Atlantic. Retrieved March 25, 2020 (https://www.theatlantic.com/technology/archive/2020/03/what-really-doomed-americas-coronavirus-response/608596/).

Ustawa z dnia 2 marca 2020 r. o szczególnych rozwiązaniach związanych z zapobieganiem, przeciwdziałaniem i zwalczaniem COVID-19, innych chorób zakaźnych oraz wywołanych nimi sytuacji kryzysowych (The Act of March 2, 2020 on special solutions related to the prevention, prevention and eradication of COVID-19, other infectious diseases and crisis situations caused by them)

Waltner-Toews, David, Annibale Biggeri, Bruna De Marchi, Silvio Funtowicz, Mario Giampietro, Martin O'Connor, Jerome R. Ravetz, Andrea Saltelli, and Jeroen P. van der Sluijs. 2020. „Post-Normal Pandemics: Why Covid-19 Requires a New Approach To Science.” Discover Society. Retrieved March 28, 2020 (https://discoversociety.org/2020/03/27/post-normal-pandemics-why-covid-19-requiresa-new-approach-to-science/).

Woodcock, Jamie. 2018. „Digital labour in the university: understanding the transformations of academic work in the UK." tripleC: Communication, Capitalism \& 
Critique. Open Access Journal for a Global Sustainable Information Society 16(1): 129-142. https://doi.org/10.31269/triplec.v16i1.880

Ye, Rebecca. 2020. „Student migration during a global health pandemic.” Discover

Society. Retrieved March 27, 2020 (https://discoversociety.org/2020/03/26/student-migration-during-a-global-health-pandemic/).

\section{BIOGRAPHICAL NOTE}

Marcin Deutschmann is a teaching assistant in sociology and a doctoral student in linguistics at the University of Opole working in the areas of critical discourse analysis and intercultural communication. He has been coordinator of the Buddy Mentors Programme at the University of Opole since 2018.

Michał Wanke is an assistant professor of sociology at the University of Opole working in the areas of digital media, illicit drugs and migrations. He is a co-creator and coordinator of Intercultural Communication MA programme in Sociology. He was appointed the coordinator of the Office for International Study Programmes at the University of Opole in 2017 - 2019.

OPEN ACCESS: This article is distributed under the terms of the Creative Commons Attribution Non-commercial License (CC BY-NC 4.0) which permits any non-commercial use, and reproduction in any medium, provided the original author(s) and source are credited. 